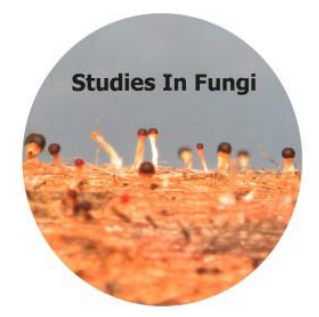

\title{
Knoxdaviesia with $K$. serotectus (Van der Linde \& Jol. Roux) Z.W. de Beer \& M.J. Wingf. a new world record from the gut of red palm weevils
}

\author{
Moubasher AH ${ }^{1,2 *}$, Abdel-Sater MA ${ }^{1,2}$ and Zeinab Soliman ${ }^{2}$ \\ ${ }^{1}$ Assiut University, Faculty of Science, Department of Botany and Microbiology, P.O. Box 71516, Assiut, Egypt \\ ${ }^{2}$ Assiut University, Assiut University Mycological Centre, P.O. Box 71516, Assiut, Egypt
}

Moubasher AH, Abdel-Sater MA, Zeinab Soliman 2017 - Knoxdaviesia with K. serotectus (Van der Linde \& Jol. Roux) Z.W. de Beer \& M.J. Wingf. a new world record from the gut of red palm weevils. Studies in Fungi 2(1), 64-70, Doi 10.5943/sif/2/1/8

\begin{abstract}
During surveys of the mycota inhabiting guts of insect species in Assiut area, Egypt, two interesting isolates were obtained from two different gut samples (out of 11 investigated) of the red palm weevil (Rhynchophorus ferrugineus Olivier). These isolates were identified phenotypically as Knoxdaviesia serotectus ( $\equiv$ Gondwanamyces serotectus). The isolates were deposited in the Assiut University Mycological Centre Culture Collection and given AUMC numbers, AUMC 10299 and AUMC 10293. Brief descriptions and photos are presented. This species is recorded here for the first time worldwide from the gut of red palm weevils.
\end{abstract}

Key words - Assiut - Gondwanamyces - insect gut - Rhynchophorus ferrugineus

\section{Introduction}

This investigation lies in the domain of environmental mycology that clearly characterizes the laboratory of mycology in the Department of Botany and Microbiology and Assiut University Mycological Centre, Egypt. It is an extension of the extensive surveys performed in different environments in Egypt: in soil, air, phyllosphere and phylloplane, rhizosphere and rhizoplane, carposphere and carpoplane, seeds and grains and food materials, which extended for approximately 50 years. The achievements were very fruitful with regard to the unprecedented broad knowledge of fungi in Egypt, which was culminated by the establishment of a large Culture Collection of fungi embraced by the Mycological Centre, Assiut University. Only a small percentage of the total fungal species on earth are known, suggested to be 1.62 million (Hawksworth 1991), 9.9 million (Cannon 1997), 2.27 million (Hawksworth 2001), or 3.5-5.1 million (O'brien et al. 2005). However, it is likely that the true number of fungal species on the planet is a seven-digit number, and may even be an order of magnitude higher (Bass \& Richards 2011). Mycologists are strongly urged to work to search for new species or records in the different ecosystems around them.

The genus Knoxdaviesia M.J. Wingf., P.S. van Wyk \& Marasas was described for K. proteae, the asexual state of a species described at the same time as Ceratocystiopsis proteae M.J. Wingf., P.S. van Wyk \& Marasas (Wingfield et al. 1988). Marais et al. (1998) proposed the sexual morph genus Gondwanamyces Marais \& M.J. Wingf. with G. proteae (M.J. Wingf., P.S. Van Wyk \& 
Marasas) Marais \& M.J. Wingf. as type species, to accommodate two ophiostomatoid species Ceratocystiopsis proteae (Wingfield et al. 1988) and Ophiostoma capense M.J. Wingf. \& P.S. van Wyk (Wingfield \& van Wyk 1993). These species are unique in having Knoxdaviesia asexual states and differ from each other in their ascospore morphology, and both are sensitive to cycloheximide, a typical of Ceratocystis. These species were transferred to the new genus as Gondwanamyces proteae and G. capense (M.J. Wingf. \& P.S. van Wyk) Marais \& M.J. Wingf. The genus Gondwanamyces is characterized by black, globose to subglobose perithecia, with relatively long necks, tapered towards the apex, asci evanescent and hyaline, ascospores hyaline, aseptate, with or without a sheath, asexual state Knoxdaviesia forming phialoconidia holoblastically from obovoid conidiogenus cells. Later, sequence data showed that they could be accommodated in the asexual state Custingophora (Kolarik \& Hulcr 2009).

Custingophora Stolk, Hennebert \& Klopotek, was introduced in 1968 by Stolk \& Hennebert (1968) with C. olivacea Stolk, Hennebert \& Klopotek as the type species, isolated from compost in Germany. Custingophora species have mononematous conidiophores that terminate in obovoid conidiogenous cells with distinct collarettes and conidia in drops of slime. The sequence data from the large subunit (LSU) ribosomal RNA gene suggested that species of Gondwanamyces and $C$. olivaceae are phylogenetically related and their morphological similarity suggests that Gondwanamyces and $C$. olivaceae have a shared ancestry and speculate that the divergence between the ancestral state of Knoxdavesia and Custingophora occurred (Viljoen et al. 1999). Until recently Gondwanamyces spp. were known only from southern Africa either specific to the infructescences of Protea repens L. (G. proteae) or in the floral parts of many Protea sp. $(G$. capense). However, Kolarik \& Hulcr (2009) described two more species, Custingophora cecropiae M. Kolarik and G. scolytodis M. Kolarik from galleries in the sapwood of Cecropia angustifolia Trecul in Costa Rica. C. cecropiae from Costa Rica is associated with a scolytid beetle, Scolytus unipunctatus Blandford (Kolarik \& Hulcr 2009). The discovery of Gondwanamyces on native trees in the Neotropics in Central America calls to question a hypothesis that these fungi are specific to the southern hemisphere (Roets et al. 2009).

In November 2011, two more species of Gondwanamyces species (G. serotectus Van der Linde \& Jol. Roux and G. ubusi Van der Linde \& Jol. Roux) were identified both were associated with damage caused by beetles (Cossonus sp.) to native Euphorbia ingens trees from South Africa in their decline and death phase. These authors transferred also Custingophora cecropiae to Gondwanamyces as G. cecropiae (M. Kolarik) Van der Linde, Jol. Roux \& M.J. Wingfield.

In June 2012, one more species from South Africa, Gondwanamyces wingfieldii Roets \& Dreyer was described as the first species of the genus collected from the infructescences of Protea (P. kaffra) from outside the boundaries of the Cape Floral Kingdom of South Africa, that Protea species has one of the widest distributions of all Protea spp. and extends from the KwaZulu-Natal Drakensberg in South Africa northwards into tropical Africa (Roets et al. 2012).

In November 2013, a new species of Custingophora, C. blanchettei Marinc., Z.W. de Beer, M.J. Wingf., C.A. Perez was described from Uruguay, near Maldonado, on soft wood of a Phytolacca dioica (Marincowitz et al. 2013).

Species of Gondwanamyces and their Custingophora asexual states form a strongly supported monophyletic clade that is sister to the Ceratocystidaceae. The morphology of the asexual morphs of Gondwanamyces is distinctive supporting a new family, Gondwanamycetaceae Réblová, W. Gams \& Seifert in the Microascales to accommodate species of this genus (Réblová et al. 2011).

Viljoen et al. (1999) showed that the asexual state genus Custingophora was closely related to Gondwanamyces, and Kolařík \& Hulcr (2009) subsequently suggested that Knoxdaviesia and Custingophora should be treated as synonyms. This suggestion was rejected by Van der Linde et al. (2012), but De Beer et al. (2013) concur with the separate treatment of these genera and applied one fungus one name principles accepted at the $18^{\text {th }}$ International Botanical Congress held in Melbourne during July 2011 (Hawksworth 2011, Hawksworth et al. 2011) under which Knoxdaviesia, the oldest name, has priority over Gondwanamyces. Knoxdaviesia was thus redefined to accommodate the asexual morph species previously treated in Gondwanamyces and 
provide new combinations where needed and nine Knoxdaviesia species were treated (Knoxdaviesia capensis M.J. Wingf. \& P.S. van Wyk, K. cecropiae (M. Kolařík) Z.W. de Beer \& M.J. Wingf., K. scolytodis (M. Kolařík) Z.W. de Beer \& M.J. Wingf., K. proteae M.J. Wingf., P.S. van Wyk \& Marasas, K. serotectus (Van der Linde \& Jol. Roux) Z.W. de Beer \& M.J. Wingf., K. suidafrikana (Morgan-Jones \& R.C. Sinclair) Z.W. de Beer \& M.J. Wingf., K. ubusi (Van der Linde \& Jol. Roux) Z.W. de Beer \& M.J. Wingf., K. undulatistipes (Pinnoi) Z.W. de Beer \& M.J. Wingf. and K. wingfieldii (Roets \& Dreyer) Z.W. de Beer \& M.J. Wingf. Also, Custingophora is presently known only from its asexual state $C$. olivacea Stolk, Hennebert \& Klopotek (De Beer et al. 2013).

\section{Materials \& Methods}

During research of filamentous and yeast fungi in Egypt in guts of three insect species, namely honey bees (Apis mellifera L.) (Apidae, Hymenoptera) and black beetles (Pterostichus melanarius Illiger) (Carabidae, Coleoptera), and to our knowledge, for the first time worldwide from the gut of adult red palm weevils, (RPW) (Rhynchophorus ferrugineus Olivier) (Curculionidae, Coleoptera) (Fig. 1), yeasts and filamentous fungi were isolated more frequently in guts of RPW than in honey bees and black beetles (Moubasher et al. 2016, in prep.). Two filamentous isolates related to dematiaceous hyphomycetes were recovered on yeast malt extract agar, (YM) (Wickerham 1951) at $28^{\circ} \mathrm{C}$ from the guts of two different gut samples of RPW. For identification, these isolates were grown on malt extract agar (MEA) and potato dextrose agar (PDA) (Samson et al. 2004). The plates were incubated at $25^{\circ} \mathrm{C}$ for $7-15$ days. For micromorphological observations, microscopic mounts were made in lactophenol cotton blue.
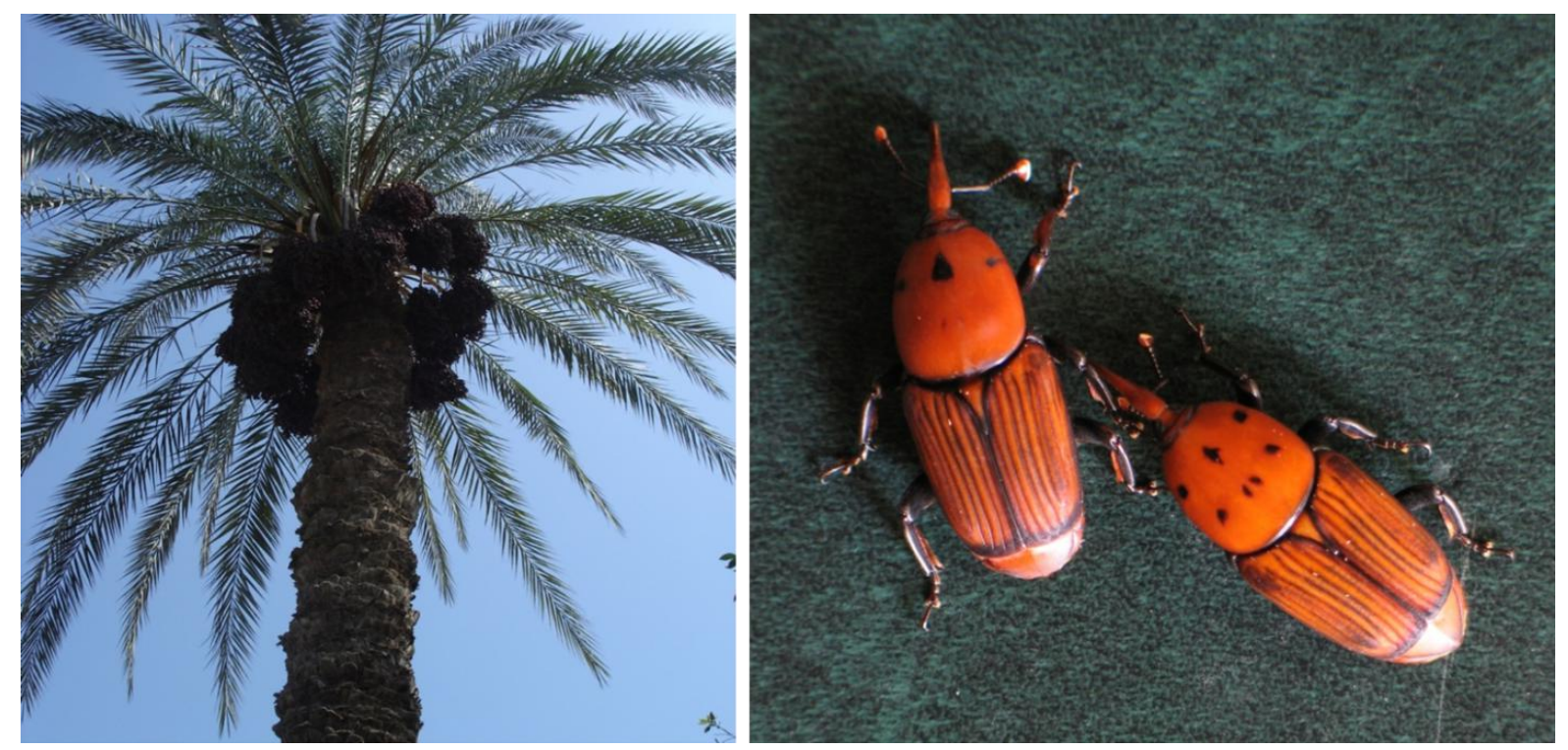

Fig. 1 - Date palm tree (left) and red palm weevil: Rhynchophorus ferrugineus (right).

\section{Results}

Identification could designate the two isolates to Knoxdaviesia serotectus ( $\equiv$ Gondwanamyces serotectus).

Knoxdaviesia serotecta (J.A. van der Linde \& Jol. Roux) Z.W. de Beer \& M.J. Wingf., in de Beer, Seifert \& Wingfield, CBS Biodiversity Series 12: 298 (2013).

Figs. 2-3

$\equiv$ Gondwanamyces serotectus J.A. van der Linde \& Jol. Roux, Mycologia 104: 5782012.

Facesoffungi number: FoF 03252.

The current strains are similar in their macro and micro-morphology to Knoxdaviesia serotectus. In brief, colonies fast growing on PDA than on MEA at $25^{\circ} \mathrm{C}$, conidiophores arising from finger-shaped rhizoids, conidiophores dark-brown, 50-150 $\times 5 \mu \mathrm{m}$, wider at the base (6-7 
$\mu \mathrm{m})$, slightly thinner at the apex $(5 \mu \mathrm{m}), 2-4$-septate, terminating into globose vesicles (Aspergillus-like), 7-10 $\mu \mathrm{m}$ diameter, vesicles bearing 4-10 conidiogenous cells, conidiogenous cells with distinct collarettes, often proliferating into secondary conidiophores bearing conidiogenous cells, conidia rounded at base and apex, oblong, hyaline, aseptate, 8-10 $\times 4-5 \mu \mathrm{m}$, conidia darken after 2 weeks, sexual state not observed.
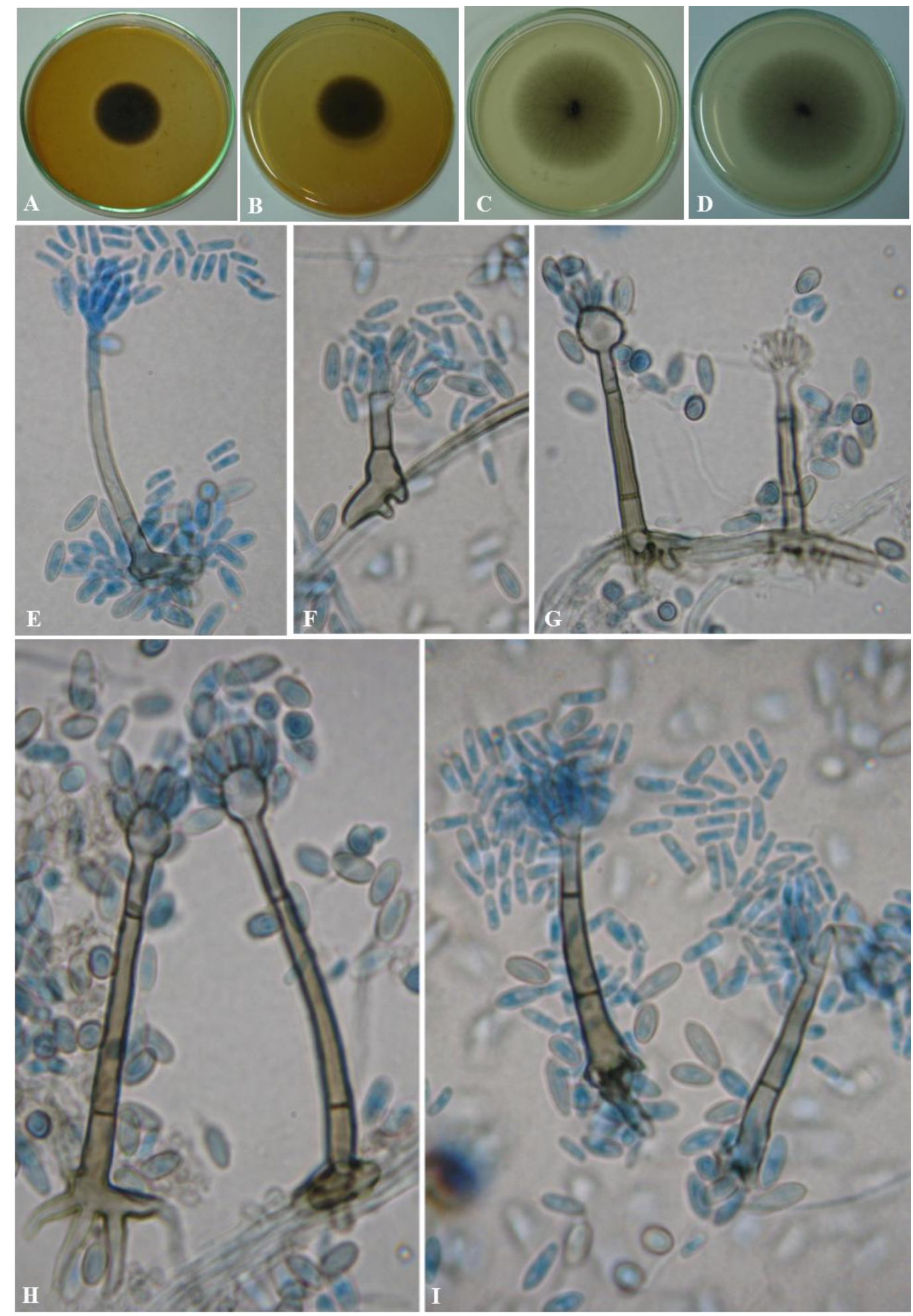

Fig. 2 - Knoxdaviesia serotectus (AUMC 10299). A Culture obverse on MEA. B Reverse on MEA. C Obverse on PDA. D Reverse on PDA. E-I Foot cells with finger-shaped rhizoids, dark brown, septate conidiophores ending with vesicles, bearing conidiogenous cells and aseptate, cylindrical slimy phialoconidia. 


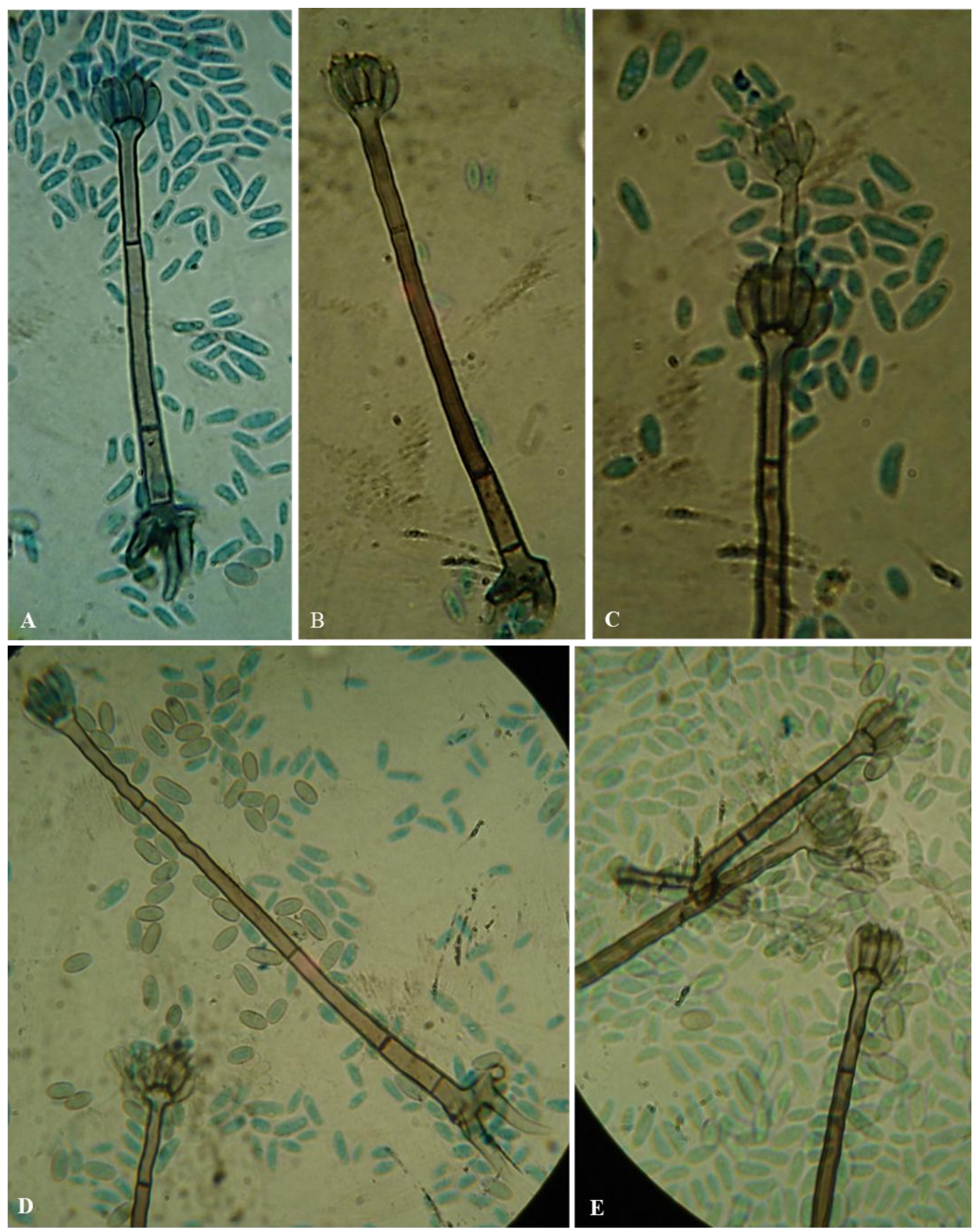

Fig. 3 - Knoxdaviesia serotectus (AUMC 10299). A, B, D. Foot cell with finger-shaped rhizoids giving rise to brown, 1-4 septate conidiophores. C Proliferation arising from the vesicle. E Subapical proliferation and proliferation from the vesicle.

\section{Ecology}

The present strains were isolated on July 2013 from the gut of Rhynchophorus ferrugineus (kindly supplied by the Faculty of Agriculture, Assiut University). This is the second record after its first description by Van der Linde et al. (2012) from discolored plant material from Euphorbia ingens and from the bodies of the weevil Cossonus, but the first from the gut of red palm weevils. These strains were deposited at the Culture Collection of Assiut Universiy Mycological Centre and given numbers AUMC 10299 and AUMC 10293. 


\section{Discussion}

Knoxdaviesia serotectus (as Gondwanamyces serotectus) was first isolated from discolored plant material from Euphorbia ingens, as well as from the bodies of the weevil Cossonus from South Africa, Limpopo Province in May 2009 and known only from four strains (Van der Linde et al. 2012). The present two strains were isolated from the gut of red palm weevils on July 2013 and this is the second record after its first description by Van der Linde et al. (2012).

Van der Linde et al. (2012) evaluated the pathogenicity of the Knoxdaviesia species they described including $K$. serotectus and found that both produced lesions on healthy succulent branches of Euphorbia ingens in contrast to the control inoculation in which internal lesion development and discoloration was absent. This suggests that these fungi and the insects that carry them could play a role in the decline of E. ingens in Limpopo Province.

The association of a Knoxdaviesia sp. with insects is not unexpected given that K. proteae and $K$. capensis occur in insect-infested Protea infructescences and initially were thought to be vectored by one or more of the insects in this niche (Wingfield et al. 1988). The insect species Genuchus hottentottus Fabricius collected from Protea repens infructescences was confirmed as carrier of $K$. proteae using PCR-based method and this suggests that there may be a symbiotic relationship between the plants, vector insect, and (or) the fungus (Roets et al. 2006). However, $K$. proteae DNA and ascospores were identified on diverse lineages of arthropods including beetles (Euderes lineicolis and Genuchus hottentottus), bugs (Oxycarenus maculates), a psocopteran species and five mite (Acari) species but based on isolation frequency, a mite species in the genus Trichouropoda appears to be the most common vector of $K$. proteae (Roets et al. 2006, 2011).

\section{Acknowledgement}

Assiut University Mycological Centre, Assiut University, Egypt is acknowledged for the financial support.

\section{References}

Bass D, Richards TA. 2011 - Three reasons to re-evaluate fungal diversity 'on Earth and in the ocean'. Fungal Biology Reviews 25, 159-164.

Cannon PF. 1997 - Diversity of the Phyllachoraceae with special reference to the tropics In: Biodiversity of Tropical Microfungi, (ed KD Hyde). Hong Kong University Press, Hong Kong, pp 255-278.

De Beer ZW, Seifert KA, Wingfield MJ. 2013 - A nomenclator for ophiostomatoid genera and species in the Ophiostomatales and Microascales. Biodiversity Series 12, 245-322.

Hawksworth DL. 1991 - The fungal dimension of biodiversity: magnitude, significance and conservation. Mycological Research 95, 641-655.

Hawksworth DL. 2001 - The magnitude of fungal diversity: the 1.5 million species estimate revisited. Mycological Research 105, 1422-1432.

Hawksworth DL. 2011 - A new dawn for the naming of fungi: impacts of decisions made in Melbourne in July 2011 on the future publication and regulation of fungal names. MycoKeys $1,7-20$.

Hawksworth DL, Crous PW, Redhead SA, Reynolds DR et al. 2011 - The Amsterdam declaration on fungal nomenclature. IMA Fungus 2, 105-112.

Kolařík M, Hulcr J. 2009 - Mycobiota associated with the ambrosia beetle Scolytodes unipunctatus (Coleoptera: Curculionidae, Scolytinae). Mycological Research 113, 44-60.

Marais GJ, Wingfield MJ, Viljoen CD, Wingfield BD. 1998 - A new Ophiostomatoid genus from Protea infructescences. Mycologia 90, 136-141.

Marincowitz S, Wingfield MJ, de Beer ZW, Perez CA. 2013 - Custingophora blanchettei Marinc., Z.W. de Beer, M.J. Wingf., C.A. Perez, sp. nov. Fungal Planet description sheet 205. Persoonia 31, 276-277. 
O'brien HE, Parrent JL, Jackson JA, Moncalvo J-M, Vilgalys R. 2005 - Fungal community analysis by large-scale sequencing of environmental samples. Applied and Environmental Microbiology 71, 5544-5550.

Réblová M, Gams W, Seifert KA. 2011 - Monilochaetes and allied genera of the Glomerellales, and a reconsideration of families in the Microascales. Studies in Mycology 68, 163-191.

Roets F, Pryke JS, Dreyer LL. 2012 - Gondwanamyces wingfieldii Roets \& Dreyer, sp. nov. Fungal Planet Description Sheet 109. Persoonia 28, 144-145.

Roets F, Wingfield MJ, Crous PW, Dreyer LL. 2009 - Fungal radiation in the Cape Floristic Region: an analysis based on Gondwanamyces and Ophiostoma. Molecular Phylogenetics and Evolution 51, 111-119.

Roets F, Wingfield MJ, Dreyer LL, Crous PW, Bellstedt DU. 2006 - A PCR-based method to detect Ophiostoma and Gondwanamyces from the surface of insects colonizing Protea flowers. Botany 84, 989-994.

Roets F, Wingfield MJ, Wingfield BD, Dreyer LL. 2011 - Mites are the most common vectors of the fungus Gondwanamyces proteae in Protea infructescences. Fungal Biology 115, 343-350.

Samson RA, Hoekstra, ES, Frisvad, JC (eds) 2004 - Introduction to Food-and Airborne Fungi. 7-th edition. Centraalbureau voor Schimmelcultures (CBS), Utrecht, Netherlands, pp 389.

Stolk H, Hennebert GL. 1968 - New species of Thysanophora and Custingophora gen. nov. Persoonia 5, 189-199.

Van der Linde JA, Six DL, Wingfield MJ, Roux J. 2012 - New species of Gondwanamyces from dying Euphorbia tree in South Africa. Mycologia 104, 574-584.

Viljoen CD, Wingfield BD, Wingfield MJ. 1999 - Relatedness of Custingophora olivaceae to Gondwanamyces spp. from Protea spp. Mycological Research 103, 497-500.

Wickerham LJ. 1951 - Taxonomy of yeasts. Department of Agricuture, Washington DC, Technical Bulletin No. 1029,

Wingfield MJ, van Wyk PS. 1993 - A new species of Ophiostoma from Protea infructescences in South Africa. Mycological Research 97, 709-716.

Wingfield MJ, van Wyk PS, Marasa WFO. 1988 - Ceratocystiopsis proteae sp. nov., with a new anamorph genus. Mycologia 80, 23-30. 